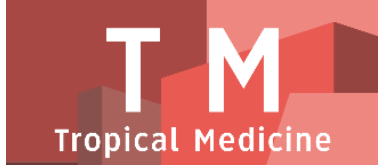

PAPER - OPEN ACCESS

Efek Ekstrak Biji Labu Kuning Terhadap Glukosa, Kolesteroldan Gambaran Histopatologi Pankreas Tikus Hiperkolesterolemia-Diabetes
Author
: Joni Tandi
DOI
: 10.32734/tm.v1i3.280
Electronic ISSN
: 2623-0542
Print ISSN
: 2623-0550

Volume 1 Issue 3 - 2018 TALENTA Conference Series: Tropical Medicine (TM)

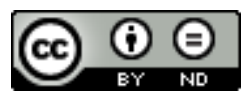

This work is licensed under a Creative Commons Attribution-NoDerivatives 4.0 International License.

Published under licence by TALENTA Publisher, Universitas Sumatera Utara
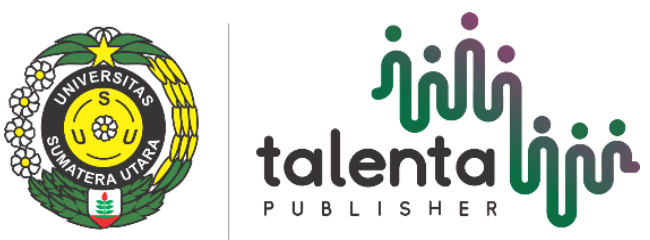


\section{idi i \\ TALENTA Conference Series}

talentabijo
Available online at https://talentaconfseries.usu.ac.id

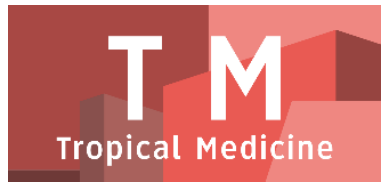

\title{
Efek Ekstrak Biji Labu Kuning Terhadap Glukosa, Kolesteroldan Gambaran Histopatologi Pankreas Tikus Hiperkolesterolemia-Diabetes
}

\author{
Joni Tandi*, Rahmawati, Rini Isminarti, Jerry Lapangoyu \\ Program Studi S1 Farmasi, STIFA Pelita Mas Palu
}

Jonitandi757@yahoo.com

\begin{abstract}
Abstrak
Hiperkolesterolemia adalah peningkatan kadar kolesterol di dalam darah melebihi batas yang diperlukan oleh tubuh. Penelitan ini bertujuan menguji kandungan senyawa fitokimia ekstrak etanol biji labu kuning, efek pemberian ekstrak etanol biji labu kuning dan perbedaan efek ekstrak dengan dosis bertingkat terhadap penurunan degenerasi sel beta pankreas tikus putih jantan hiperkolesterolemia diabetes. Penelitian eksperimen laboratorium ini menggunakan hewan uji sebanyak 30 ekor tikus dibagi dalam enam kelompok perlakuan. Kelompok 1 (kontrol normal) diberikan Na-CMC 0,5\% dan kelompok 2 (kontrol negatif) diberi pakan tinggi kolesterol, suspensi Streptozotocin $35 \mathrm{mg} / \mathrm{kgBB}$ dan Na-CMC 0,5\% b/v; kelompok 3 diberi metformin 9 $\mathrm{mg} / \mathrm{kgBB}$ per oral, pakan tinggi kolesterol dan suspensi streptozotocin $35 \mathrm{mg} / \mathrm{kgBB}$; kelompok 4, 5 dan 6 masing-masing diberikan dosis 270,360 , dan $450 \mathrm{mg} / \mathrm{kgBB}$ per oral, pakan tinggi kolesterol dan suspensi streptozotocin $35 \mathrm{mg} / \mathrm{kgBB}$. Gambaran tingkat kerusakan histopatologi pankreas diamati dengan pewarnaan HE menggunakan mikroskop Olympus BX-51 perbesaran 200x. Hasil penelitian menunjukkan: Terdapat senyawa alkaloid, flavonoid, polifenol, saponin,dan tannin pada ekstrak etanol biji labu kuning; ekstrak etanol biji labu kuning dosis 360 dan $450 \mathrm{mg} / \mathrm{kgBB}$ efektif menurunkan degenerasi jaringan pankreas tikus hiperkolesterolemia diabetes dan pemberian ekstrak etanol biji labu kuning dosis $270 \mathrm{mg} / \mathrm{kgBB}$ tidak memberikan efek maksimal jika dibandingkan dengan dosis $360 \mathrm{mg} / \mathrm{kgBB}$ dan dosis $450 \mathrm{mg} / \mathrm{kgBB}$ terhadap regenerasi sel organ pankreas tikus putih jantan hiperkolesterolemia diabetes.
\end{abstract}

Kata kunci : Labu Kuning, Histopatologi, Pankreas.

\begin{abstract}
Abstrak
Hypercholesterolemia is an increase in cholesterol levels in the blood beyond the limits required by the body. This research is aimed to examine the content of phytochemical compound, the effect of ethanol extract and the effect difference of extract of pumpkin seed with stratified dosage on the regeneration of pancreatic beta cells of male white mouse hypercholesterolemia diabetic. This laboratory experimental study used a total of 30 rats which divided into six treatment groups. Group 1 (normal control) was given 0.5\% NaC CMC and group 2 (pain control) were fed with high cholesterol, suspension Streptozotocin 35 $\mathrm{mg} / \mathrm{kgBW}$ and $\mathrm{Na}-\mathrm{CMC} 0.5 \% \mathrm{w} / \mathrm{v}$; group 3 were given metformin $9 \mathrm{mg} / \mathrm{kgBW}$ orally, high cholesterol feed and $35 \mathrm{mg} / \mathrm{kgBW}$ streptozotocin suspension; groups 4, 5 and 6 were each given a dose of 270, 360, and $450 \mathrm{mg} / \mathrm{kgBW}$ orally, high cholesterol feed and a $35 \mathrm{mg} / \mathrm{kgBW}$ streptozotocin suspension. Description of the extent of pancreatic histopathologic damage observed with HE staining using Olympus BX-51 microscope with 200x magnification. The results showed that: there was secondary metabolite compound on ethanol extract of pumpkin seeds; ethanol extract of pumpkin seedling dose 360 and $450 \mathrm{mg} / \mathrm{kgBW}$ effectively regenerate pancreatic tissue of diabetic hypercholesterolemia rat and administration of yellow pumpkin ethanol extract dose 270 $\mathrm{mg} / \mathrm{kgBW}$ did not give maximum effect when compared with a dose of $360 \mathrm{mg} / \mathrm{kgBW}$ and a dose of $450 \mathrm{mg} / \mathrm{kgBW}$ to regeneration of pancreatic organ cells of diabetic white male diabetic hypercholesterolemia.
\end{abstract}

Keywords: Pumpkin Seeds (Cucurbita moschata Duchesne), Histopathology, Pancreas.

\section{Pendahuluan}

(C) 2018 The Authors. Published by TALENTA Publisher Universitas Sumatera Utara

Selection and peer-review under responsibility of Seminar Nasional Tanaman Obat Indonesia Ke 54 
Bangsa Indonesia telah lama mengenal dan menggunakan obat tradisional sebagai pencegahan, pengobatan, dan menambah daya tahan tubuh. Pengetahuan tentang tanaman berkhasiat obat berdasarkan pada pengalaman dan keterampilan yang secara turun temurun telah diwariskan oleh nenek moyang kita [1]. Pemanfaatan obat tradisional oleh masyarakat sebagai pengobatan alternatif untuk diri sendiri. Obat tradisional sudah dikenal dimulai dari informasi turun temurun, kemudian khasiatnya di konfirmasi dengan hasil penelitian ilmiah [2].

Labu kuning banyak dibudidayakan di negara-negara Afrika, Amerika, India, dan Cina. Tanaman ini mampu tumbuh di dataran rendah maupun tinggi dengan ketinggian antara $0 \mathrm{~m}-1500 \mathrm{~m}$ diatas permukaan laut [3]. Biji labu kuning (Cucurbita moschata Duchesne) mengandung senyawa alkaloid, saponin, kukurbitasin, lesitin, resin, stearin, senyawa fitosterol, fenolik, asam lemak, squalen, tirosol, asam vanilat, vanillin, luteolin dan asam sinapat, vitamin (termasuk vitamin $\beta$-karoten, vitamin $A$, vitamin B2, $\alpha$-tokoferol, vitamin C dan vitamin E) [4]. sehingga dipercaya masyarakat sebagai antidiabetes.

Menurut American Diabetes Association (ADA) tahun 2015, diabetes merupakan suatu penyakit kronis kompleks yang membutuhkan perawatan medis yang lama atau terus menerus dengan cara mengendalikan kadar gula darah untuk mengurangi risiko multifaktoral (American Diabetes Asssociation. 2015). International Diabetes Federation (IDF) memperkirakan bahwa 318 orang mengalami gangguan toleransi glukosa. IDF juga memperkirakan bahwa pada tahun 2015 lima juta orang meninggal karena penyebab yang terkait dengan diabetes. Indonesia merupakan negara urutan ke-7 dengan kejadian diabetes mellitus tertinggi setelah Cina (98,4 juta), India (65,1 juta), Amerika (24,4 juta), Brazil (11,9 juta), Rusia (10,9 juta), Mexico (8,7 juta), Indonesia (8,5 juta) (Internasional Diabetes Federation. 2015).

Hiperkolesterolemia adalah peningkatan kadar kolesterol di dalam darah melebihi batas yang diperlukan oleh tubuh. Peningkatan kadar kolesterol dalam darah merupakan salah satu faktor penting perkembangan penyakit arteri koroner dan sangat berperan terhadap gangguan kardiovaskular yang disebut aterosklerosis. Hiperkolesterolemia terjadi karena dipengaruhi oleh beberapa faktor yaitu faktor genetik, jenis kelamin, umur, dan diet. Seseorang dikatakan menderitahiperkolesterolemia bila kadar kolesterol total plasma melebihi keadaan normal yaitu $\geq 240 \mathrm{mg} / \mathrm{dL}$ [5].

Pankreas merupakan organ kelenjar penting dalam tubuh yang terdiri dari jaringan eksokrin dan endokrin.Kelenjar endokrin pankreas tersusun atas pulau Langerhans yang merupakan cluster yang tersebar di sepanjang kelenjar eksokrin pankreas. Unit endokrin yang disebut sebagai pulau Langerhans memiliki 4 macam sel, yaitu sel alfa $(\alpha)$, sel beta $(\beta)$, sel delta $(\delta)$, dan sel $F$ (polipeptida pankreas). Sel beta menghasilkan hormon insulin dan berperan dalam menurunkan kadar glukosa darah. Perubahan histopatologis pulau Langerhans dapat terjadi secara kuantitatif, seperti pengurangan jumlah atau ukuran, maupun secara kualitatif, seperti terjadi nekrosis (kematian sel), atropi (pengecilan sel), dan fibrinosis (jaringan-jaringan sel yang rusak). Sel-sel yang rusak akibat bahan kimia dapat menyebabkan inflamasi (peradangan). Kerusakan sel-sel beta pankreas dapat disebabkan faktor genetik, infeksi oleh kuman, dan radikal bebas [6].

Histopatologi sangat penting dalam kaitan dengan diagnosis penyakit karena salah satu pertimbangan dalam penegakan diagnosismelalui hasil pengamatan terhadap jaringan yang diduga terganggu. Analisis kondisi histologi organ / jaringan dengan pengamatan terhadap perubahan morfologi, struktur dan indikasi kerusakan/infeksi/mutasi lainnya akibat pengaruh penyakit, bahan toksik atau proses-proses mutagenisis lainnya.

Penelitian yang dilakukan oleh Primawati menyatakan bahwa kadar fenolik total serta aktivitas antioksidan pada biji labu kuning berturut-turut sebesar 3,9489 mg asam galat / gram sampel dan 47,11\%. Penelitian yang dilakukan oleh Rivi menyatakan aktivitas antioksidan dan fenolik total pada tempe dengan penambahan biji labu kuning menyatakan bahwa biji labu kuning pada konsentrasi $10 \%$ memiliki kadar fenolik yang tinggi sebagai sumber antioksidan, sedangkan penelitian yang dilakukan oleh Li F.S menyatakan bahwa dalam biji labu kuning terdapat senyawa fenolik yang dapat meredam reaksi berantai radikal bebas [10]. Penelitian ini secara umum bertujuan untuk menguji pengaruh pemberian ekstrak etanol biji labu kuning terhdap regenerasi sel $\beta$ pankreas tikus model hiperkolesterolemia diabetes yang diinduksi streptozotocin, sehingga penelitian ini diharapkan mampu memberikan informasi ilmiah bagi masyarakat mengenai khasiat biji labu kuning yang tidak hanya mengobati penyakit, tetapi juga dapat mempengaruhi struktur histologis sel-sel organ.

\section{Metode Penelitian}

Metode penelitian yang digunakan adalah metode eksperimental dengan rancangan pretest postest randomized controlled group design Besar sampel ditentukan berdasarkan jumlah kelompok yakni 6 kelompok, setiap kelompok terdiri dari 5 ekor tikus, sehingga besar sampel pada penelitian ini sebanyak 30 ekor, kontrol normal 5 ekor, kontrol sakit (negatif) 5 ekor, kontrol positif 5 ekor, kelompok perlakuan yaitu suspensi ekstrak etanol biji labu kuning dosis $270 \mathrm{mg} / \mathrm{kg}$ BB 5 ekor, suspensi ekstrak etanol biji labu kuning dosis $360 \mathrm{mg} / \mathrm{kg}$ BB 5 ekor, dan suspensi ekstrak etanol biji labu kuning dosis $450 \mathrm{mg} / \mathrm{kg}$ BB 5 ekor.

\subsection{Alat Dan Bahan}

Alat : Ayakan 40, batang pengaduk (Pyrex), blender (National), cawan porselin, corong kaca (Pyrex), erlenmeyer (Pyrex), gelas kimia (Pyrex), gekas ukur (Pyrex), gegep kayu, glukometer (Accu Chek), glukotest strip test(Accu Chek), jarum oral, kandang hewan uji, labu ukur (Pyrex), labu alas bulat (Schott Duran), mortir dan stamper, pipet tetes, rotary Vaccum Evaporator (Eyela), sentrifuge, spektofotometri UV-Vis

Bahan : Air suling, asam klorida (Merck), besi (III) klorida (Merck), biji Labu Kuning (Cucurbita moschata Duchesne), citrate-buffer saline, etanol absolute 96\% (Merck), formalin $10 \%$, kapas (Pro medic), kertas saring, kloroform (Merck), larutan 
Mayer Hematoxylin-Eosin, larutan iodium, liebermann-Burchard(Merck), Na CMC 0,5\% (Bioworld), natrium hidroksida , natrium klorida 0,9\% dan $10 \%$ (PT. Widatra Bhakti), pakan standar, pakan tinggi kolesterol (Pakan standar 80\%, pig oil 15\%, kuning telur bebek 5\%), serbuk magnesium (Merck), streptozotocin (Bioworld USA), dan tablet metformin (PT. Dexa Medica)

\subsection{Populasi Dan Sampel Penelitian}

Populasi penelitian meliputi tikus putih jantan galur wistar yang diperoleh dari Malang Murine Farm (MMF) sebanyak 30 ekor sedangkan biji labu kuning sebagai sampel penelitian diperoleh dari Desa Kalukubula Kecamatan Sigi Biromaru Kabupaten Sigi, Provinsi Sulawesi Tengah.

\subsection{Pembuatan Ekstrak Etanol Biji Labu Kuning}

Pembuatan ekstrak etanol biji labu kuning dilakukan dengan metode maserasi, yaitu simplisia biji labu kuning yang telah dijadikan serbuk, kemudian diayak menggunakan ayakan mesh nomor 40, ditimbang 1000 gram lalu diekstraksi dengan menggunakan pelarut etanol 96\% sebanyak 5 L dengan cara maserasi selama 3 x 24 jam terlindung dari cahaya sambil sesekali diaduk. Ekstrak kemudian disaring menggunakan kertas saring lalu diperoleh filtrat. Selanjutnya dievaporasi atau memisahkan larutan menggunakan Rotary Vaccum Evaporator pada suhu $60^{\circ} \mathrm{C}$ dan didapat ekstrak pekat kemudian diuapkan dengan menggunakan waterbath dengan suhu $60^{\circ} \mathrm{C}$ hingga diperoleh ekstrak kental biji labu kuning.

\subsection{Pembuatan Tikus Hiperkolesterolemia- Diabetes}

Tikus diberikan pakan standar (80\%), pig oil (15\%), dan kuning telur bebek (5\%).

\subsection{Pengukuran Kadar Glukosa Darah}

Pengukuran kadar glukosa darah tikus menggunakan alat Accu Check.

\subsection{Pembuatan Preparat Histopatologi Pankreas}

Hewan uji dimatikan dengan cara dislokasi leher. Hewan yang telah mati diletakkan di atas papan fiksasi dengan perut mengarah ke atas.Pemotongan dilakukan pada bagian kulit perut secara menyilang sampai terlihat bagian organ dalam perut tikus. Selanjutnya diambil organ pankreas tikus, lalu disimpan dalam wadah khusus yang berisi formalin $10 \%$.

\subsubsection{Pembuatan Sediaan Histologi Pankreas}

Setelah pankreas dikeluarkan dari tubuh tikus, dilakukan pembuatan preparat pankreas dengan langkah sebagai berikut: Sampel pankreas yang telah diambil lalu di fiksasi dengan larutan formalin 10\% selama 3-4 jam.

\subsubsection{Pembuatan Preparat dan Pewarnaan HE Histologi}

Pembuatan preparat histopatologi dilakukan dengan beberapa tahap yaitu :Tahapan fiksasi, sampel dilarutkan dengan larutan formalin 10\% selama 3-4 jam, tahapan dehidrasi, sampel dicuci dengan aseton sebanyak 3 kali, masing-masing selama 2 jam, tahapan cleaning (pembersihan), sampel dicuci dengan menggunakan toluen sebanyak 3 kali, masing- masing selama 1-2 jam,tahapan embedding yaitu perendaman sampel di paraffin cair dengan suhu $60^{\circ} \mathrm{C}$ sebanyak 3 kali, masing-masing selama 2 jam, lalu dilakukan proses pencetakan blok paraffin. Blok parafin yang terbentuk diiris menggunakan alat mikrotom sehingga menghasilkan lembaran yang ketebalannya $2 \mu \mathrm{m}$, lalu lembaran tersebut diletakkan di penangas air dengan suhu $30^{\circ} \mathrm{C}$, lembaran yang telah direndam dalam penangas dilengketkan pada objek glass, lalu sampel tersebut dipanaskan di oven selama 2-3 menit, dan tahapan pewarnaan, sebelum pewarnaan, sampel yang telah dipanaskan di oven lalu direndam dalam xylol sebanyak 3 kali masing-masing selama 5-10 menit. Selanjutnya dilakukan pencucian/pembilasan menggunakan alkohol $90 \%$ selama 5-10 menit, lalu alkohol 80\% selama 5-10 menit dan kemudian alkohol 70\% selama 5-10 menit. Setelah itu dilakukan proses pewarnaan menggunakan larutan haemotoxylin selama 2-3 menit dan dilanjutkan dengan larutan Eosin selama 2-3 menit. Kemudian sampel dicuci/dibilas menggunakan alkohol 70\% selama 5-10 menit, lalu alkohol 80\% selama 5-10 menit dan kemudian alkohol 90\% selama 5-10 menit. Sampel dikeringkan pada suhu kamar selama 3-5 menit lalu ditutup dengan objek glass, lalu diamati di bawah mikroskop.

\section{Hasil dan Pembahasan}

\subsection{Hasil Penelitian}

Uji penapisan fitokimia dilakukan untuk membuktikan adanya golongan senyawa metabolit sekunder yang terdapat pada ekstrak dan hasilnya adalah sebagai berikut. 
Tabel 1. Hasil Uji Penapisan Fitokimia

\begin{tabular}{cccc}
\hline No & Parameter Uji & Pereaksi & Hasil \\
\hline 1 & Alkaloid & Dragendorff & Endapan warna merah jingga \\
2 & Flavanoid & $\mathrm{HCl} \mathrm{Pekat}$ & Terbentuk warna merah ungu \\
3 & Polifenol & $\mathrm{FeCl}_{3}$ & Terbentuk hijau kebiruan \\
4 & Saponin & $\mathrm{HCl} 2 \mathrm{~N}$ & Terbentuk buih yang menetap tidak kurang 1 menit \\
5 & Tanin & $\mathrm{FeCl}_{3}$ & Terbentuk warna hijau kehitaman \\
+
\end{tabular}

Tabel 2. Rerata Kadar Glukosa Sebelum Dan Setelah Perlakuan

\begin{tabular}{|c|c|c|c|c|c|c|c|}
\hline \multirow[b]{2}{*}{ Hari ke- } & \multicolumn{7}{|c|}{ Rerata \pm SD Kadar Glukosa Darah (mg/dL) } \\
\hline & $\begin{array}{l}\text { Kontrol } \\
\text { Normal }\end{array}$ & $\begin{array}{l}\text { Kontrol } \\
\text { Negatif }\end{array}$ & $\begin{array}{l}\text { Kontrol Positif } \\
\text { (Metformin) }\end{array}$ & $\begin{array}{l}\text { Dosis } 270 \\
\mathrm{mg} / \mathrm{kgBB}\end{array}$ & $\begin{array}{l}\text { Dosis } 360 \\
\mathrm{mg} / \mathrm{kgBB}\end{array}$ & $\begin{array}{l}\text { Dosis } 450 \\
\mathrm{mg} / \mathrm{kgBB}\end{array}$ & $\mathrm{P}$ \\
\hline 0 & $107 \pm 17.7$ & $101.4 \pm 7.5$ & $90.4 \pm 4.5$ & $94 \pm 7.5$ & $91.4 \pm 9.1$ & $92.2 \pm 6$ & 0.073 \\
\hline 31 & $106.4 \pm 13.6$ & $250.4 \pm 60.4$ & $369.6 \pm 127.1$ & $381.6 \pm 115.7$ & $370 \pm 83.7$ & $417.6 \pm 85.1$ & 0.000 \\
\hline 38 & $90.8 \pm 10.2$ & $280.8 \pm 50.1$ & $168 \pm 86.6$ & $188.6 \pm 67.9$ & $159.2 \pm 34.3$ & $183.8 \pm 66$ & 0.002 \\
\hline 45 & $90.8 \pm 7.3$ & $295.6 \pm 51.3$ & $106.6 \pm 36.9$ & $119.8 \pm 27.6^{*}$ & $111.2 \pm 16.2$ & $115.6 \pm 27.5$ & 0.000 \\
\hline
\end{tabular}

Sumber : Data Primer, 2017

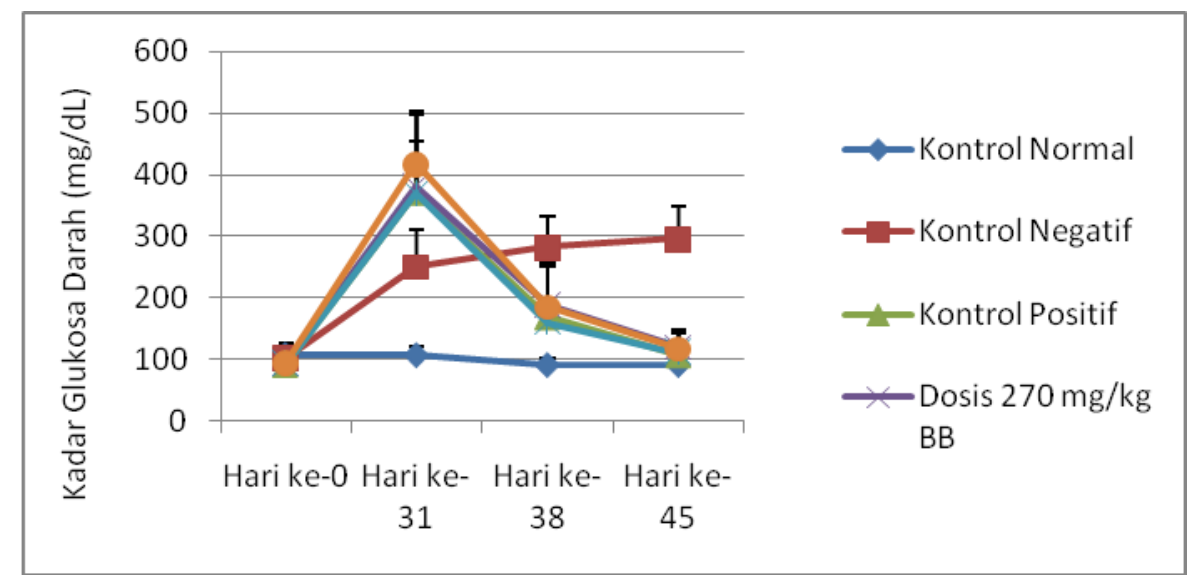

Gambar 1 Profil kadar glukosa darah tikus putih jantan setiap kelompok pada hari ke-0, Hari ke-31, Hari ke-38 dan Hari ke-45

Tabel 3. Rerata kadar kolesterol total sebelum dan setelah perlakuan

\begin{tabular}{|c|c|c|c|c|c|c|c|}
\hline \multirow[b]{2}{*}{$\begin{array}{c}\text { Hari } \\
\text { ke- }\end{array}$} & \multicolumn{7}{|c|}{ Rerata \pm SD kadar kolesterol total (mg/dL) } \\
\hline & $\begin{array}{c}\text { Kontrol } \\
\text { normal } \\
152 \pm 60.81\end{array}$ & Kontrol negatif & $\begin{array}{c}\begin{array}{c}\text { Kontrol positif } \\
\text { (simvastatin) }\end{array} \\
112 \pm 12.72\end{array}$ & $\begin{array}{c}\text { Dosis } 270 \mathrm{mg} / \mathrm{kg} \\
\text { BB } \\
148.8 \pm 57.27\end{array}$ & $\begin{array}{l}\text { Dosis } 360 \\
\mathrm{mg} / \mathrm{kg} \mathrm{BB} \\
123 \pm 19.79\end{array}$ & $\begin{array}{c}\text { Dosis } 450 \mathrm{mg} / \mathrm{kg} \\
\text { BB } \\
157.5 \pm 47.37\end{array}$ & $\begin{array}{c}\mathrm{P} \\
0.937\end{array}$ \\
\hline 31 & $161 \pm 35,35$ & $278.5 \pm 16.26$ & $279.5 \pm 2.12$ & $299.5 \pm 41.71$ & $279 \pm 14.14$ & $296 \pm 7.07$ & .000 \\
\hline 38 & $159 \pm 43.84$ & $308 \pm 39.59$ & $212 \pm 5.65$ & $265.5 \pm 30.40$ & $239.5 \pm 7.77$ & $266 \pm 8.48$ & .000 \\
\hline 45 & $131 \pm 21.21$ & $302.5 \pm 33.23$ & $148 \pm 2.82$ & $227 \pm 12.72$ & $159 \pm 11.31$ & $220.5 \pm 31.81$ & .000 \\
\hline
\end{tabular}

Sumber : Data Primer, 2017 


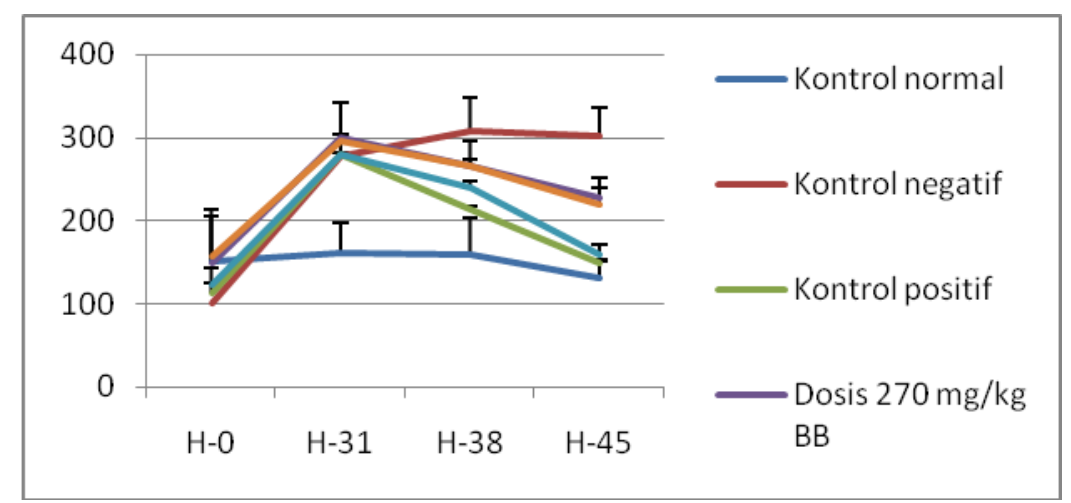

Gambar 2 Profil kadar kolesterol total tikus putih jantan setiap kelompok pada hari ke-0,

Hari ke-31, Hari ke-38 dan Hari ke-45

Tabel 4. Rerata Derajat Nekrosis Pankreas Tikus Putih Jantan Hiperkolesterolemia Diabetes Setelah Pemberian Ekstrak Etanol Biji Labu Kuning.

\begin{tabular}{|c|c|c|c|c|c|c|c|}
\hline \multirow[b]{2}{*}{ Hari Ke - } & \multirow[b]{2}{*}{$\begin{array}{l}\text { Kontrol } \\
\text { Normal }\end{array}$} & \multicolumn{5}{|c|}{ Rerata Derajat Nekrosis Jaringan pankreas Pankreas \pm SD } & \multirow[b]{2}{*}{$\mathrm{P}$} \\
\hline & & Kontrol Sakit & Kontrol Positif & $\begin{array}{l}\text { Dosis } 270 \\
\mathrm{mg} / \mathrm{kgBB}\end{array}$ & $\begin{array}{l}\text { Dosis } 360 \\
\mathrm{mg} / \mathrm{KgBB}\end{array}$ & Dosis $450 \mathrm{mg} / \mathrm{kgBB}$ & \\
\hline \multirow{5}{*}{45} & 0 & 4 & 2 & 3 & 2 & 2 & \multirow{6}{*}{0,000} \\
\hline & 0 & 4 & 2 & 3 & 2 & 2 & \\
\hline & 0 & 3 & 2 & 3 & 3 & 3 & \\
\hline & 0 & 4 & 2 & 3 & 2 & 2 & \\
\hline & 0 & 3 & 1 & 3 & 2 & 2 & \\
\hline Rerata \pm SD & $0 \pm 0$ & $3,6 \pm 0,547$ & $1,8 \pm 0,447$ & $3 \pm 0$ & $2,2 \pm 0,447$ & $2,2 \pm 0,447$ & \\
\hline
\end{tabular}

Pada hari ke-45 menunjukkan adanya perbedaan yang nyata pada masing-masing kelompok yang ditandai dengan nilai $\mathrm{P}$ $<0,05$ yaitu 0,000 .

3.2. Hasil Pengamatan Histologi Sel Pankreas Tikus Putih Jantan Dengan Pewarnaan Hematoksilin-Eosin Berdasarkan Skoring Gambar hasil pengamatan terhadap organ pankreas tikus secara mikroskopis yang memperlihatkan adanya perbedaan gambaran histopatologi pankreas berdasarkan skoring tingkat kerusakan dengan pewarnaan HE 0

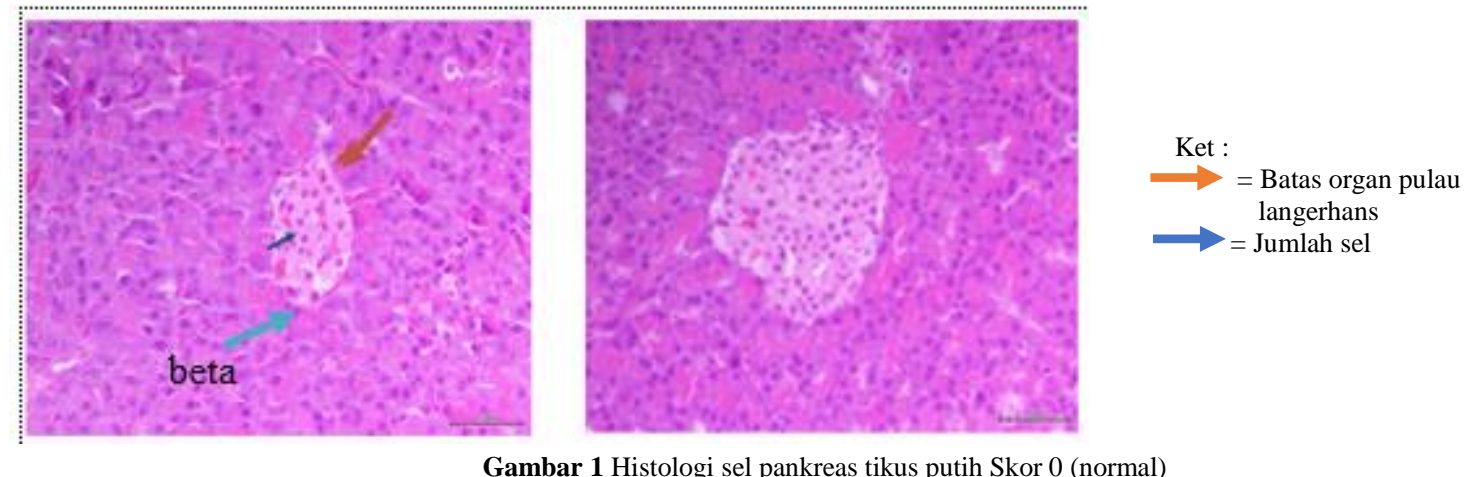

Skor 0 tampak bentuk sel normal, tidak adanya perubahan dari batas organ pulau langerhans, serta tidak terjadi nekrosis pada sel.
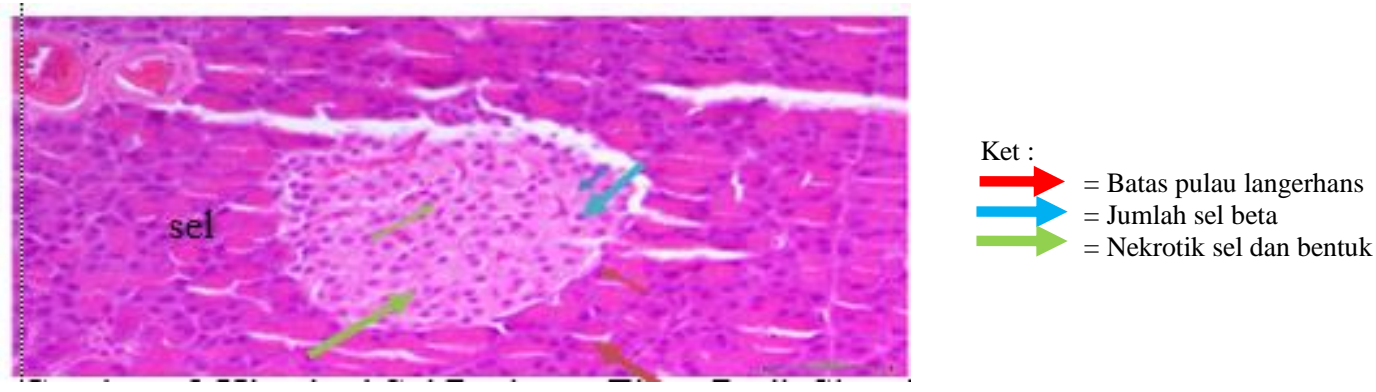

Gambar 2 Histologi Sel Pankreas Tikus Putih Skor 1 
Skor 1 tampak, tidak bentuk sel normal adanya perubahan dari batas organ pulau langerhans, jumlah sel mulai berkurang serta tidak terjadi nekrosis pada sel hanya terlihat degenerasi sel
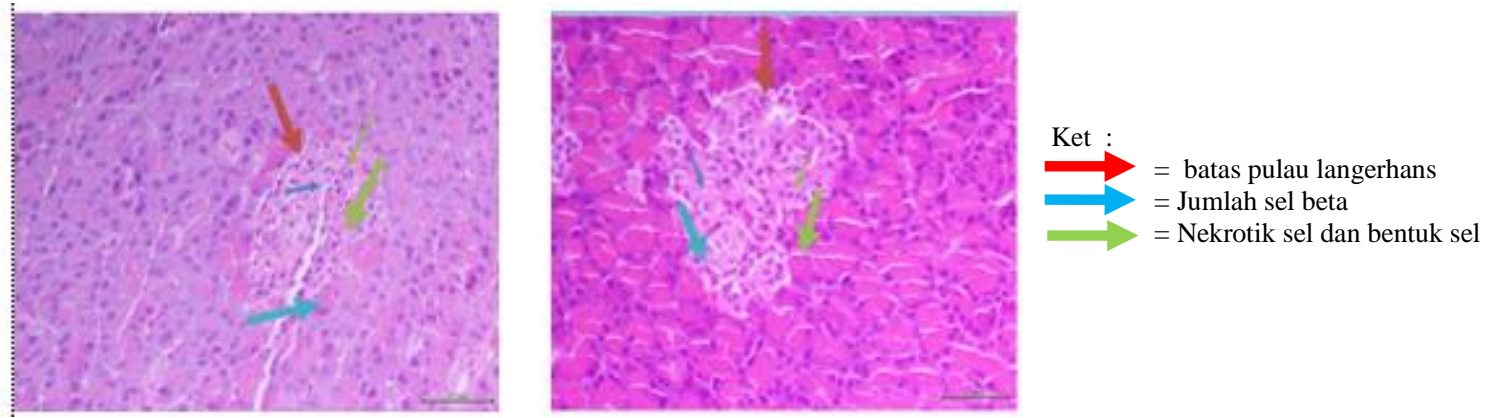

Skor 2 tampak adanya bentuk sel yang tidak normal, terjadi perubahan dari batas organ pulau langerhans menjadi tidak jelas, jumlah sel mulai berkurang serta tidak terjadi nekrosis pada sel hanya terlihat degenerasi sel

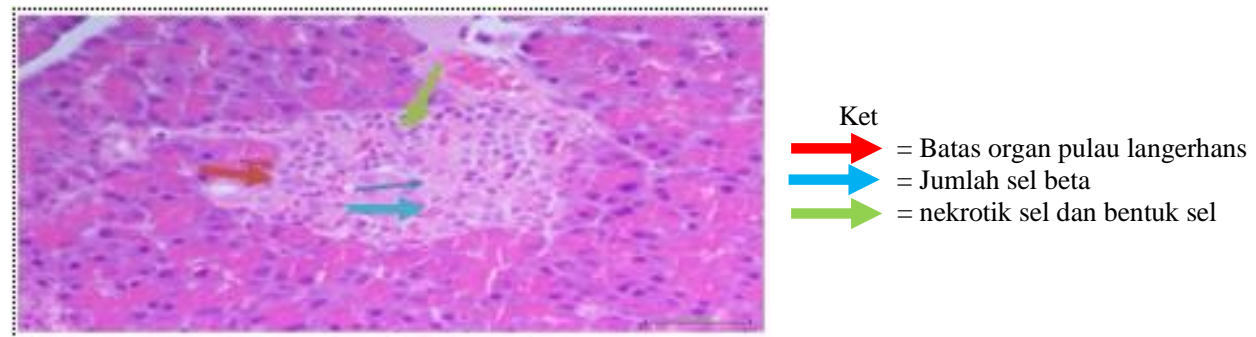

Gambar 4 Histologi Sel Pankreas Tikus Putih Skor 3

Skor 3 tampak terlihat bentuk sel yang tidak normal, terjadi perubahan dari batas organ pulau langerhans menjadi tidak jelas, jumlah sel mulai berkurang serta terjadi nekrosis pada sebagian besar sel.

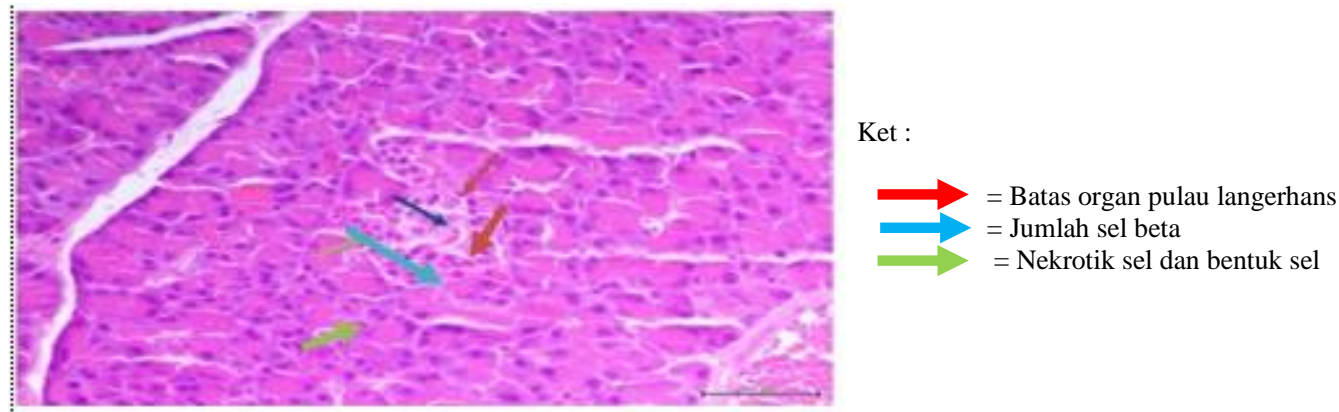

Gambar 5 Histologi Sel Pankreas Tikus Putih Skor 4

Skor 4 tampak bentuk sel tidak normal, terjadi perubahan dari batas organ pulau langerhans menjadi sangat tidak jelas, jumlah sel banyak yang berkurang serta hampir keseluruhan sel terjadi nekrosis.

\subsection{Pembahasan}

Pada penelitian ini tikus yang digunakan merupakan tikus putih jantan hal ini karena kondisi biologisnya lebih stabil dibandingkan dengan tikus betina dan tidak dipengaruhi oleh adanya siklus estrus serta tikus jantan juga mempunyai kecepatan metabolisme obat yang lebih cepat. Tikus diadaptasikan selama 2 minggu di laboratorium biofarmasetika STIFA untuk menyesuaikan pola hidup pada lingkungan baru dan mencegah terjadinya stres pada saat perlakuan.

Berdasarkan hasil statistik one way Anova pada hari ke-45 memperlihatkan nilai yang menunjukan bahwa dosis 270 mg/kg BB sudah memberikan efek yang berarti dalam menurunkan kadar glukosa darah karena kontrol normal tidak diberikan perlakuan apapun. Dosis $270 \mathrm{mg} / \mathrm{kg}$ BB berbeda signifikan dengan kontrol negatif hal ini menunjukan dosis $270 \mathrm{mg} / \mathrm{kg} \mathrm{BB}$ sudah memberikan efek yang berarti dalam menurunkan kadar glukosa darah karena kontrol negatif hanya diberikan Na CMC sebagai Kontrol. Jika dibandingkan dengan kontrol positif dosis $270 \mathrm{mg} / \mathrm{kg}$ BB berbeda tidak signifikan hal ini menunjukan bahwa dosis $270 \mathrm{mg} / \mathrm{kg}$ BB sudah memberikan efek yang berarti dalam menurunkan kadar glukosa darah karena memberikan efek yang sama

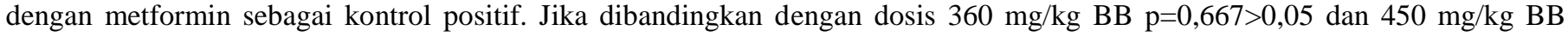


$\mathrm{p}=0,833>0,05$ menunjukan berbeda tidak signifikan dengan dosis $270 \mathrm{mg} / \mathrm{kg} \mathrm{BB}$ yang berarti dosis $270 \mathrm{mg} / \mathrm{kg} \mathrm{BB} \mathrm{memberikan}$ efek yang sama dengan dosis $360 \mathrm{mg} / \mathrm{kg} \mathrm{BB}$ dan $450 \mathrm{mg} / \mathrm{kg}$ BB.

Dosis $360 \mathrm{mg} / \mathrm{kg}$ BB berbeda tidak signifikan dengan kontrol normal hal ini menunjukan dosis $360 \mathrm{mg} / \mathrm{kg} \mathrm{BB}$ sudah memberikan efek yang berarti dalam menurunkan kadar glukosa darah. Dosis $360 \mathrm{mg} / \mathrm{kg}$ BB berbeda signifikan dengan kontrol negatif hal ini menunjukan bahwa dosis $360 \mathrm{mg} / \mathrm{kg}$ BB sudah memberikan efek yang berarti dalam menurunkan kadar glukosa

Dosis $450 \mathrm{mg} / \mathrm{kg}$ BB berbeda tidak signifikan dengan kontrol normal hal ini menunjukan dosis $360 \mathrm{mg} / \mathrm{kg} \mathrm{BB}$ sudah memberikan efek yang berarti dalam menurunkan kadar glukosa darah. Dosis $450 \mathrm{mg} / \mathrm{kg}$ BB berbeda signifikan kontrol negatif hal ini menunjukan bahwa dosis $450 \mathrm{mg} / \mathrm{kg}$ BB sudah memberikan efek yang berarti dalam menurunkan kadar glukosa darah.

Hasil uji statistik One Way Anova kadar kolesterol total pada hari ke-45 memperlihatkan nilai $\mathrm{p}=0,000(\mathrm{p}<0,05)$ menunjukkan adanya perbedaan yang signifikan pada setiap kelompok perlakuan pada hari ke-45 sehingga dilakukan uji lanjut Post Hoc Test LSD untuk melihat perbedaan yang bermakna setiap perlakuan. Hasil uji lanjut Post Hoc Test LSD menunjukkan kontrol negatif berbeda signifikan kontrol normal, kontrol positif dan 3 kelompok perlakuan (dosis $270 \mathrm{mg} / \mathrm{kg} \mathrm{BB}, 360 \mathrm{mg} / \mathrm{kg}$ BB dan 450 $\mathrm{mg} / \mathrm{kg} \mathrm{BB}$ ) karena pada kontrol negatif kadar kolesterol tikus masih tinggi, dimana kontrol negatif hanya diberikan suspensi Na CMC yang tidak dapat menurunkan kadar kolesterol, sedangkan kontrol positif berbeda signifikan dengan dosis $270 \mathrm{mg} / \mathrm{kg} \mathrm{BB}$ dan $450 \mathrm{mg} / \mathrm{kg} \mathrm{BB}$ dan berbeda tidak signifikan dengan Kontrol normal dan dosis $360 \mathrm{mg} / \mathrm{kg}$ BB hal ini menunjukkan bahwa ekstrak etanol biji labu kuning dosis $360 \mathrm{mg} / \mathrm{kg}$ BB lebih efektif menurunkan kadar kolesterol total pada tikus putih jantan yang hampir sebanding dengan kontrol positif.

Penurunan kadar kolesterol total oleh ekstrak etanol biji labu kuning disebabkan adanya kandungan alkaloid, flavonoid, fenolik, saponin dan tanin yang dapat menurunkan kadar kolesterol total. Senyawa flavonoid dan fenolik menurunkan kadar kolesterol darah dengan cara meningkatkan ekskresi asam empedu dan bersifat sebagai antioksidan yang mampu mereduksi LDL (Low Density Lipoprotein) dan trigliserida, sehingga menghambat penumpukan LDL di dinding pembuluh darah (Carvajall Zarrabal et al. 2005). Tanin memiliki kemampuan dalam mengikat asam empedu di usus dan dibuang melalui feses, dapat menurunkan kolesterol total darah. Flavonoid dan tanin juga dapat menghambat kerja HMG-CoA reduktase dan asil-koenzim A kolesterol asiltransferase (ACAT) yang merupakan enzim untuk mensintesis kolesterol dan absorpsi kolesterol serta pelepasannya ke darah. Tanin diketahui dapat memacu metabolisme glukosa dan lemak, sehingga timbunan kedua sumber kalori ini dalam darah dapat dihindari.

Berdasarkan hasil analisis Mann-whitney menunjukkan bahwa ada perbedaan yang signifikan pada gambaran histopatologi pankreas tikus dari masing-masing kelompok perlakuan $(\mathrm{p}<0,05)$ diantaranya yaitu kelompok kontrol normal berbeda signifikan dengan semua kelompok $(\mathrm{p}<0,05)$. Kelompok kontrol negatif berbeda signifikan dengan dengan kelompok kontrol normal, kelompok kontrol positif, kelompok perlakuan dosis $360 \mathrm{mg} / \mathrm{kg}$ BB dan $450 \mathrm{mg} / \mathrm{kg} \mathrm{BB}(\mathrm{p}<0.05)$ tetapi tidak berbeda signifikan dengan kelompok perlakuan dosis $270 \mathrm{mg} / \mathrm{kg}$ BB $(\mathrm{p}>0,05)$. Kelompok kontrol positif berbeda signifikan dengan kelompok kontrol normal dan kelompok perlakuan dosis $270 \mathrm{mg} / \mathrm{kg} \mathrm{BB}(\mathrm{p}<0,5)$ tetapi berbeda tidak signifikan dengan kelompok perlakuan dosis $360 \mathrm{mg} / \mathrm{kgBB}$ dan $450 \mathrm{mg} / \mathrm{kg}$ BB (p>0,05). Kelompok perlakuan dosis $270 \mathrm{mg} / \mathrm{kg}$ BB berbeda signifikan kelompok kontrol normal, kelompok kontrol positif, kelompok pelakuan dosis $360 \mathrm{mg} / \mathrm{kg}$ BB dan $450 \mathrm{mg} / \mathrm{kg}$ BB (p<0,5) tetapi berbeda tidak signifikan dengan kelompok kontrol negatif ( $\mathrm{p}>0,05)$. Kelompok perlakuan dengan dosis $360 \mathrm{mg} / \mathrm{kg}$ BB berbeda signifikan dengan kelompok kontrol normal dan kelompok perlakuan dosis $270 \mathrm{mg} / \mathrm{kg} \mathrm{BB}(\mathrm{p}<0,5)$ tetapi berbeda tidak signifikan dengan kelompok kontrol positif dan kelompok perlakuan dosis $450 \mathrm{mg} / \mathrm{kg}$ BB (p>0,05). Kelompok perlakuan dosis $450 \mathrm{mgkg}$ BB berbeda signifikan dengan kontrol normal dan kelompok perlakuan dosis $270 \mathrm{mg} / \mathrm{kg} \mathrm{BB}(\mathrm{p}<0,5)$ tetapi berbeda tidak signifikan dengan kelompok kontrol positif dan kelompok perlakuan dosis $360 \mathrm{mg} / \mathrm{kg}$ BB ( $>0,05)$. Berdasarkan hasil pengamatan preparat histopatologi pankreas tikus dan analisis yang dilakukan, terbukti bahwa pemberian ekstrak etanol biji labu kuning mempunyai efek terhadap gambaran histopatologi pankreas tikus yang diinduksi streptozotocin. Ditinjau dari pemberian ekstrak etanol biji labu kuning pada dosis $270 \mathrm{mg} / \mathrm{kgBB}, 360 \mathrm{mg} / \mathrm{kgBB}$ dan $450 \mathrm{mg} / \mathrm{kg}$ BB sudah mempunyai efek terhadap gambaran histopatologi pankreas tikus, tetapi pada dosis $270 \mathrm{mg} / \mathrm{kg}$ BB efeknya tidak terlalu baik dibanding dengan dosis $360 \mathrm{mg} / \mathrm{kgBB}$ dan dosis $450 \mathrm{mg} / \mathrm{kgBB}$ yang mempunyai efek lebih baik. Hal ini terjadi karena dalam dosis tersebut zat aktif yang terkandung dalam ekstrak biji labu kuning jumlahnya lebih banyak sehingga kerusakan pankreas yang terjadi semakin membaik. Regenerasi sel pankreas tikus berkaitan erat dengan kandungan zat aktif pada labu kuning yaitu flavonoid. Flavonoid memiliki mekanisme yaitu menurunkan kadar glukosa darah dengan meningkatkan sekresi insulin .

Pada kontrol positif tampakadanya bentuk sel yang tidak normal, terjadi perubahan dari batas organ pulau langerhans menjadi tidak jelas, jumlah sel mulai berkurang serta tidak terjadi nekrosis pada sel hanya terlihat degenerasi sel. Hal ini menunjukkan tingkat kerusakan jika dibandingkan dengan kontrol negatif. Pada kelompok dosis $270 \mathrm{mg} / \mathrm{kg}$ BBtampak terlihat bentuk sel yang tidak normal, terjadi perubahan dari batas organ pulau langerhans menjadi tidak jelas, jumlah sel mulai berkurang serta terjadi nekrosis pada sebagian besar sel. Hasil ini menunjukkan adanya penurunan kerusakan dibandingkan dengan kontrol negatif tetapi penurunan kerusakannya kecil. Pada dosis $360 \mathrm{mg} / \mathrm{kg}$ BB dan dosis $450 \mathrm{mg} / \mathrm{kg}$ BB ,tampak adanya bentuk sel yang tidak normal, terjadi perubahan dari batas organ pulau langerhans menjadi tidak jelas, jumlah sel mulai berkurang serta tidak terjadi nekrosis pada sel hanya terlihat degenerasi sel. Hal ini menunjukkan adanya penurunan tingkat kerusakan dibandingkan dengan kontrol negatif. Penurunan ini lebih baik dibandingkan dengan dosis $270 \mathrm{mg} / \mathrm{kg}$ BB karena pada dosis 360 dan $450 \mathrm{mg} / \mathrm{kg}$ BB jumlah zat aktif lebih banyak dibandingkan dengan dosis $270 \mathrm{mg} / \mathrm{kg}$ BB sehingga efek yang ditimbulkan juga lebih baik. 


\section{Kesimpulan}

Berdasarkan hasil penelitian maka dapat disimpulkan bahwa biji labu kuning (Cucurbita moschata Duchesne) memberikan efek terhadap penurunan kadar glukosa darah, kolesterol total dan meregenerasi jaringan pankreas tikus putih jantan (Rattus norvegiscus) hiperkolesterolemia diabetes.

\section{Daftar Pustaka}

[1] Sampurno. 2007, Obat Herbal Dalam Perspektif Medik dan Bisnis.Fakultas Farmasi Universitas Gadjah Mada, Yogyakarta. 12(42). Hal. 18

[2] Permana H. 2007. Tanaman Obat Tradisional. Titian Ilmu Bandung. Bandung. Hal: 1

[3] Rukmana, R. 1997. Usaha Tani Labu. Kanisius. Yogyakarta. Hal 45.

[4] Primawati, R.(2007). Aktivitas Antioksidan dan Kadar Fenolik Total Biji Semangka (Citrullus vulgaris schrad.) dan Biji Labu Kuning (Cucurbita muschata ex poir). Skripsi. Fakultas Sains dan Matematika Universitas Kristen Satya Wacana.

[5] Tandi J., Tendean, I., Kenta, S (2017). Uji Ekstrak Etanol Daun Talas (Colosacia escuenta (L.)Schott.) Terhadap Gambaran Histopatologi Pankreas Tikus Putih Jantan (Rattus norvegicus) Hiperkolesterolemia Diabetes. Jurnal Farmasi Gelenika, 1-11.

[6] Seungbum, K., S. Jun-Seop, K. Hyun-Jung, K.C. Fisher, L. Mi-Ji and K. Chan-Wha. 2007. Streptozotocin-induced diabetes can be reversed by hepatic oval cell activation through hepatic transdifferentiation and pancreatic islet regeneration. Lab. Investigation 87. Hal. $702-712$.

[7] Tandi J, Roem M, dan Yuliet. 2017. Efek Nefroprotektif Kombinasi Ekstrak Daun Gedi Merah dan Kucing Kucing pada Tikus Induksi Etilen Glikol. STIFA Pelita Mas. Jurnal Trop Pharmacy Cemistry Vol.04 No.01. Palu. Hal 27-34

[8] Tandi J., As'ad, S., Natzir, R., \& Bukhari, A (2016). Test of Ethanol extract Red Gedi Leaves (Albelmoscus Manihot, (L) Medik) In White Rat (Rattus Norvegicus) Type 2 Diabetes Melitus. International Journal Of Sciences, 30(4), 84-94

[9] Tandi J., Hanifah, M., Yuliet., Yusriadi. 2017. Efektivitas Ekstrak Daun Gedi Merah Terhadap Glukosa Darah, Malondialdehid, 8Hidroksideoksiguanosin, Insulin Tikus Diabetes. J.Trop. Pharm. Chem. Volume 3 No. 4 hal 256-266

[10] Li. F.S. 2009. Structures of new phenolic glycosides from the seeds of cucurbita moschata. U.S. National library of medicine. Hal 511.

[11] Abd, E., Abd, K. 2011. Antimicrobial Proteins and Oil Seeds From Pumkin (Cucurbita moschata) Nature and Science. Hal 111.

[12] Akbarzadeh A, Norouzian D, Mehrabi MR, jamshadi, Farhangi A, et al. 2007. Induced Of Diabetes By Streptozotocin In Rats. Indian Journal Of Clinical Biochemistry. 22(2):60-64.

[13] American Diabetes Asssociation. 2015. Diagnosis and Classification of Diabetes Mellitus. Diabetes Care, volume 35. Suplemen 1. Hal. 5, 27, 45.

[14] Ardabili AG., Farhosh R., Khodaparast MHH. Chemical Composition and Physicochemical Properties of Pumpkin Seeds (Cucurbita pepo Subsp. pepo Var. Styriaka) Gown in Iran. J. Ag. Sci. Tech. (2011) Vol. 13. Hal. 1053-1063.

[15] Bambang, S. 1995. Materi Medika Indonesia. Jilid VI. Departemen Kesehatan RI. Jakarta. Hal 5-14A

[16] Depkes RI. 2000. Parameter Standar Umum Ekstrak Tumbuhan Obat. Direktorat BPOM. Jakarta. Hal 5,10,11.

[17] Eliasson, L. Abdulkader, F.,Braun, M., Galvanovskis, J., Hoppa, M.B and Rorsman, P. 2008. Novel aspects of the molecular mechanisme controlling insulin secretion.J Physiol. 586 (14);3313-24

[18] Fajans. S. Stefan.,Bell,I., Graime and Polonsky,S. 2001. Molecular Mechanism and Clinical Pathophysiology of Maturity-Onset Diabetes of the Young. The New England Journal of Medicine. England

[19] Internasional Diabetes Federation. 2015. IDF Diabetes Atlas. Edisi 7. Hal 9, 17, 28-29, 51.

[20] Martindale. 2007. The Complete Drug Reference. London: The Pharmaceutical Press. Hal 783.

[21] Modorwal A,Jain, and P, Bari S. 2011. Abelmoscus manihot L Medic Linn: Ethanobotany. Phytochemistry traditional Medicines. Asians Journal of Traditional Medicine. 6(1): Hal 1-7.

[22] Nugroho, A.E. 2006. Hewan Percobaan Diabetes Mellitus: Patologi Dan Mekanisme Aksi Diabetogenik Laboratorium Farmakologi Dan Toksikologi, Bagian Farmakologi Dan Farmasi Klinik, Fakultas Farmasi Universitas Gadjah Mada. Yogyakarta. Hal 381-382.

[23] Ramesh, B., Yogesh, Raghavendra, Kantikar and Prakash. 2010. Antidiabetic And istphatologycal aloxan Induced Diabetic Rats. International Journal of Drug Development \& Research Vol. 2 Hal 2

[24] Suarsana, I.N., B.P. Priosoeryanto., M.Bintang., dan T. Wresdiyati. 2010. Profil Glukosa Darah dan Ultrastruktur Sel Beta Pankreas Tikus yang Diinduksi Senyawa Aloksan. JITV Volume 15 No. 2. 118-123

[25] Shepherd PR, Khan BB. (1999). Glucose Transporter and Insulin Action. Journal of Medicine. England. Hal. 249-251

[26] Tjay, H., Rahardja, K. 2007. Obat-Obat Penting. Jakarta : PT. Gramedia. Hal 739-759.

[27] Upt. Sumber Daya Hayati Sulawesi. Kementrian Riset Teknologi Dan Pendidikan Tinggi. 2016. Universitas Tadulako.

[28] Walvekar M V*, Potphode N D, Desai S S, Deshmukh V M. 2016. Histological Studies on Islets of Langerhans of Pancreas in Diabetic Mice after Curcumin Administration. International Journal of Pharmaceutical and Clinical Research 2016; 8(9): 1314-1318

[29] Wilcox, G. 2005. Insulin and Insulin Resistance.ClinBiochem; 26(2): 19-39.

[30] Tandi, J., Rizky M., Mariani R., Alan F. 2017. Uji Efek Ekstrak Etanol Daun Sukun (Artocarpus altilitis (Parkinson Ex F.A Zom) Terhadap Penurunan Kadar Glukosa Darah, Kolesterol Total, dan Gambaran Histopatologi Pankreas Tikus Putih Jantan (Rattus norvegicus) Hiperkolesterolemia Diabetes. Jurnal Sains dan Kesehatan. Vol.1 No.8. Hal: 384-396. p-ISSN: 2303-0267, e-ISSN: 2407-6082. 